\title{
Contestation and Negotiation of Gogol's Life Regarding His Hybrid Identity in Jhumpa Lahiri's The Namesake
}

\author{
Farhana Haque, M.A \\ Department of English and Humanities, Brac University, Mohakhali, Dhaka, Bangladesh \\ dhak_121@yahoo.com
}

\begin{abstract}
The aspect of diasporic literature has got the ingrained meanings through the identity crisis. The shifting of place usually creates the notable changes in a man's scenario of origin. Then he/she get entered into the diverse cultural periphery. Fluid identity make a person's identity become complex in the age of globalization. In the $21^{\text {st }}$ century, this diasporic literature has almost seen in most of the modern writer's writing pieces. Jhumpa Lahiri is one of them. In her famous novel The Namesake, the themes of alienation, loneliness, rootlessness, homelessness and quest for identity became prominent and prevail over the other themes of this novel. Jhumpa Lahiri is a remarkable voice of Indian diaspora in America. She has decorated the Story of her novel according to her own life's diasporic experiences. There in the novel Jhumpa Lahiri has instilled the concept of dismantle culture between the two countries such as India and America. The amalgamation of the two cultures made Gogol's life became unfavourable and thus he has started to live in different social milieus. He tried to internalize both the Indian and American cultures but at last failed to recognize his own self as he was busy to adjust with the blending cultures. Jhumpa Lahiri took the issue of Gogol's expatriation as a life of contestation and negotiations. Gogol's nebulous name made his identity almost perished. This paper will explore Gogol's life's two different cultural backgrounds, different religious matters and the way of leading life in America as an immigrant.
\end{abstract}

Keywords: Hybrid identity, Diaspora community, Immigration, Namesake, Indian culture, American culture, Identity crisis.

\section{INTRODUCTION}

The word diaspora got the meaning to scatter. It gives the sense of diversity, amalgamation of different cultures and heritage alienation, topographical shifting, hybridity, transnationalism, cultural transaction fluid identity and as a whole identity crisis. In the novel The Namesake Jhumpa Lahiri has been elucidated the complex situation of Gogol's life that how he was alienated in an immigrant country like America. How he was suffered about his nebulous identity and felt him all alone. In this diasporic life Gogol was feeling homeless who has been settled his life as an expatriate which means dislocation that compelled him to bring the sense of loss and nostalgia. The Indians who have been living outside of India called as diaspora. Jhumpa Lahiri was one of them. She was suffered from her true identity hence Gogol was her shadow in the novel The Namesake. Jhumpa Lahiri was a middle class family girl who was born in London and after her parents have been shifted in Rhodes Island ( USA), she was being grown up in that country. From own experiences as a immigrant Jhumpa Lahiri has been beautifully portrayed the dual identity situation in her life. Her first novel The Namesake got the fame and alsograbbed the recognition to make its cinema on diasporic life's struggle and identity crisis. Before i proceed to the detail plot of my paper i would like to include one interview released by Houghton Miffin Company where Lahiri asserted that the novel was about those" who are culturally displaced or those who grow up in two world's simultaneously". 
To present the complex situation of the hybrid identity holder people, Lahiri said that,

"I think that for immigrants the challenges of exile, the loneliness, the constant sense of alienation, the knowledge of and longing for a lost world, are more explicit and distressing than for their children".

The Namesake was a novel about searching Gogol's identity. This war was to get the real identity which has started from Kolkata to USA. As a human being we are suppose to celebrate several types of identities such as an identity we are born into, an identity in a time of struggle, an identity in a strange land, an identity in a time of departing this world. We all are obsessed with the search of actual identity. Who we are, from where we have come, to where we shall go or to where we are eventually belongs to. When life offered us with so many options that is the time when we are forced to think that who we really are becomes a crisis itself. We are about to ensnare in a web of identity loss. In the novel The Namesake, Ashok Ganguli kept his son's name as Gogol after being attached and showed love towards his favourite Russian author Nikolai Gogol. At first Gogol Ganguli was not supposed to be the Gogol Ganguli but someone else. Unfortunately the name which was finalized by the great grandmother get lost in the mail. Gogol's identity crisis thus started right after his birth and he was remained in the condition of namelessness. For this incident all his life Gogol's predicament identity was chasing him relentlessly. After this unwanted namesake, Ashok and Ashima decided a good name which was Nikhil as per their Bengali custom of naming, but later Gogol has refused to be known as Nikhil on the first day of his kindergarten. As he was growing up in environment of USA but his origin was in India, these two identities made his life miserable and this condition plagued him to the rest of his life. He felt suffocated to bear a name which was neither Indian nor American, Gogol has found himself smashed in the middle of two contrasting and conflicting cultures, thus twisted in the thread of contestation and negotiation in his life regarding identity crisis.

\section{JHUMPA LAHIRI'S AUTOBIOGRAPHICAL STREAK AS AN IMMIGRANT SIMILAR TO THE CHARACTER GOGOL}

Jhumpa Lahiri was almost similar with Gogol in the issue of identity crisis. In an interview with Mira Nair, she said: "I wanted to please my parents and meet their expectations. I also wanted to meet the expectations of my American peers, and the expectations I put on myself to fit into American society. Its a classic case of divided identity". Like Gogol her pet name was accidently became her good name. She has two more names, one is in her passport and other one has been written in her birth certificate. In the days of her school life, the teachers has been decided that Jhumpa was the easiest of her names to pronounce. This was her diasporic crisis and she was suffered from her dual identity. In the same interview with Mira Nair she said,

"The original spark of the book was the fact that a friend of my cousin in India had a pet name Gogol. I wanted to write about a pet name/good name distinction for a long time. It is almost too perfect a metaphor for the experience of growing up as the child of immigrants, having a divided identity, divided loyalties etc.".

Again she said in the same interview that,

"The names we have, there is no much about them who are we and they are the one world that exists and represents us. And yet we don't choose them. They are from our parents".

This issue of naming varies culture to culture, while the identity becomes the predominant issue and names become important and significant. In Bengali tradition they used to keep two names, one is pet name used by the family members and close friends, while other one is used by rest of the society or world. Gogol actually knew about his identity crisis and was portrayed this plight by Jhumpa Lahiri very nicely in The Namesake. In the time of birth, Gogol's settled name was about to come through mail by the great grandmother but was lost inadvertently by his father Ashok. After that Ashok decided to Keep his son's name by one of his favourite Russian author's name Nikolai Gogol and this was the name which has been fixed and written in the Massachusetts 
hospital where he was born. This name has gone on the birth certificate and has attached to stay with him in his early school years. When he was entered in the kindergarten, Gogol was learned by his father that, he will be called by the name Nikhil, a good name. Gogol then rejected this name and wanted to be called by Gogol by society and family. This crisis regarding his name made himself fall into perpetual distress on the first day of kindergarten and it was his first try to reject his hybrid identity. When he was growing up, from that time he used to ask who he is. In his school days, once he went to a field trip and revealed the importance of identity. In a graveyard there were endorsed the members names according to their surname in the epitaph, but he could not find any Ganguli buried there. Gogol was anxious about his name as his first name Gogol which did not match neither the Indian community nor the American and as a result it demolished his innate qualities. From his birth time to the adult age Gogol was trying to discover his identity. In one stage in his college life he was desperate to change his name officially. In order to do so he changed his name as Nikhil from Gogol. He was busy doing metamorphose himself to a different persona. Gogol's this endeavour didn't work out when he noticed that his parents also call him as Nikhil at home then where is the changing thing lies? He then felt,

"In that instant that he is not related to then, not their child". (Lahiri, 106)

Being a citizen of United Sates where the non-American children are often feel uneasy from their difference from the USA natives. Likewise Gogol and his sister Sonali felt ashamed and frustrated among the original American citizens. After staying as an immigrant in America most of the children are habituated by their alienation and they know that they will be mocked and tortured mentally by the native Americans. When Gogol was reached into his adolescence time, he wanted to enter in the American society and remain unnoticed. As his origin was Indian, he though the natives Americans will never consider him as an American citizen. This was the inbetween condition of Gogol which was painful and made him as a marginalized person as an immigrants. In this novel Lahiri's experiences were almost same as Gogol who belongs to second generation Indian diaspora. Gogol and Lahiri both were in quest for identity which will have no end. As a whole they both seemed to be stranded between the country of their parents and the country of their birth. They both wanted to balance the ideologies of these two countries which are actually stay in the distant place. In this way they have lost their goal of life and thus suffered from acute identity crisis. Gogol and Lahiri both were feeling themselves as a strangers to both the countries. In India they are an American, and in America they are an Indian.

\section{THE DEFINITION OF CULTURAL DIVERSITY ACCORDING TO THE NOVEL THE NAMESAKE}

In the age of globalization, the demarcation line of culture and heritage becoming no longer useful, when there has been raised the expectations of friendliness and co-operative attitudes. Regarding the issue of dual identity holder people and their ancestor, which is still the central theme in this world. The main dilemma arises when the two different cultural people and their background meet together. Problems are happening when the host country people's issue of equation came forward. Expectations are always roaming in both the birth country and the country of origin regardless of creed, colour, religion, culture and overall the lifestyle. In this immigrant situation one society expect the other to change but they don't feel importance to change the ideologies of conducting with the diasporic community. In this way the immigrant has to suffer the plight of this unstable doctrine of the society. Eventually this problems become the same and the immigrants try to compromise between the both countries and their cultures.

\section{UNCEASINGLY DIFFICULT SITUATION REGARDING THE HYBRID IDENTITY}

The Namesake is about the struggle and search of real identity. The first generation's life is about the adaptation and acquiring new things about themselves. While the second generation people finds it as an aspect of conflict between the two cultures. Parents are always in trying to maintain ties with their home country and also try to instil their cultures and heritage in the life of their children. The children are enthralled by their fellow friends in the host country, which is no longer their own country at all. In the novel The Namesake, Gogol was suffered 
from this identity crisis and became sandwich within the countries of his parents and his birth. In India he didn't get the entire acceptance and also in America he also didn't get the proper identity from every sides of his life. Stuart Hall remarked in his essay,

"Critical points of deep and significant difference which constitute what we really are; or rather-since history has intervened-what we have became". (Hall, 112)

Gogol's identity crisis has been considered as a post-colonial issue. His identity crisis has arrived from the very first time of his birth, hence his struggled was keep going throughout his life. In order to make his identity become incorporated, Gogol tried to connect his name with the strangers names in the graveyard when he was in a school field trip. After that in his time of adolescence Gogol tried to merge his existence with American milieu, but his name did create problems to recognize himself as a pure American citizen. In the university level, Gogol has replaced his name as Nikhil and felt relieved because nobody knew his earlier name. By doing so Gogol has started his journey of transformation and wanted to do several activities which he didn't able to do when his name was Gogol. Again the dilemma Gogol has poured inside of his heart. He did change his name but was not fully satisfied with his name Nikhil as it was carrying his parents root country India. He was helpless and has been broken down from inside.

"he dies not feel like Nikhil". ( Lahiri 105)

Gogol's inner satisfaction was less when he has passed his eighteen years of life in America.

"After eighteen years of Gogol, two months of Nikhil feels scant, inconsequentive". ( Lahiri 105)

Gogol felt himself as an alien in American society though he was born and brought up in America. His parent's home country made him uneasy and infuriated because that certainly reminded him of his past heritage. Gogol tried hard to build a barrier between his past and present but he felt that is not so easy.

"Nikhil evaporates and Gogol claim him again". ( Lahiri, 106)

As a whole Gogol's identity has remained unnoticed and lost in the realm of post-colonialism. And he was suffering this identity crisis in the rest of his life.

AMBiguOUS NAME OF GOGOL

Gogol was helplessly carrying his ambiguous name which was the root of all problems. At home he was forced to follow the Bengali traditional name while in the outside of his home and among the American people he was not acceptable with his name. As he was born in America so it might be his motherland but he was not considered as an native American people, hence he was thrown as an outcast person. Gogol was very much anxious regarding his name and at last he decided to change his name as Nikhil. This was the first attempt at acquiring the extra ordinary acceptance from the society. Till his father made him realize that the name Gogol played the significant role in his father's life. The name Gogol was the emblem of his father which Gogol didn't realize at first. Towards the end of the novel The Namesake, this disgusting name Gogol became the name of legacy when his father died. As a whole Gogol's name and he himself was in doubtful situation whether he will consider him as an Indian or as an American. Gogol was unfortunate to identify himself as a person of exhilaration or bonhomie towards the American people in American society. Instead of that he was feeling like a rootless alien man on earth. In Gogol's love life he was not happy at all. From everywhere he got upset and being cheated. To the American girl friends he was like a poor guy and to his wife Moushumi he was suitable to cheat. Therefore he didn't get any family or certain home where he can put his soul to relax. All his life he did war within his own self and with his hybrid identity. Gogol was never ready to accept the identity given by his father until the very end when he has found out his identity in a book gifted to him by his father on his birthday. The sudden loss of his father made him to start the introspection about his own self and the mystery of his unfavourable name. 


\section{GOGOL'S UNFAVOURABLE FATE AND THE WAY OF LEADING RESTLESS LIFE ESSENTIALLY INCORPORATE WITH HIS DUAL IDENTITY}

Gogol was feeling stranded within his two countries of birth and his parents root country. He was considered himself as an outsider of the reality and started to contemplate over his identity. Gogol's parents wanted to make him as an Indianized boy while on the other hands his American friends were busy mocking him. For this uneasy situation he was become restless and started to hide his life's activities from his parents. In secret way he used to do smoke or going to late night parties with his friends. For the first time when he was learnt about the history of his namesake, he got furious. Nikolai Gogol, who was an Russian author and Gogol's father had kept his name after getting impressed by that Russian author's name. He felt disdain about the name of Gogol. In his university time, Gogol has decided to change his name in order to distant himself from the name 'Gogol'. He did show his restlessness in his love affairs as well. Gogol was attracted to an American girl called Ruth but soon they got separated. They were studying in literature but somehow felt to stop their way to lead life together. After this break up with Ruth, Gogol has been attached with another affair with Maxine, an Anglo-Saxon American ethnically. She was belonged to a very wealthy Manhattan family. As his love was growing stronger he has then decided to live with Maxine's family and left his own. Although they loved each other but again they broke up. As his life was going good after all these separations but in one Point his life became stopped when his father died suddenly. He got shattered and in the time of Gogol's father's death's ritual people did criticism and said he has no idea of Indian rituals being an Indian. After seeing this unwanted situation, Gogol's mother Ashima suggested him to meet with Moushumi, one of her friend's daughter, who belonged to another Bengali family. At first Gogol didn't want to meet and agree to get married with Moushumi but at the last minute he has changed his mind regarding Moushumi. Gogol was disagree to marry with Moushumi for two reasons, one was the same Bengali cultural root and another was her disgraced past. He was no way to come out from his own ideologies because his mother wanted that and he was agreed to meet with her only to please his mother. After having his first meeting with Moushumi Gogol became impressed and has begun to develop their intimacy. Although it was a date fueld by Gogol's mother. In one stage of their relationship, one day Moushumi came to known about Gogol's changed name which was Nikhil. Gogol didn't want to reveal this secret to Moushumi but somehow that exposed to her.

\footnotetext{
"He stares at her, stunned. He has never told her to tell anyone. He simply assumed she never would. His expressions is lost on her; she smiles back at him, unaware of what she's done. The dinner guests regard him, their mouths hanging open in confused smiles" ( Lahiri, 243).
}

One guest named Sally has again made Gogol remember about his past name. Sally has placed the name as belonging to the writer of short story 'overcoat' by Nikolai Gogol. That day passed like a confused manner towards Gogol. But in the issue of his love affair with Moushumi he felt enthralled. The scent of her body made his sense mesmerised and intoxicated. Moushumi's stale smell of smoking made Gogol more fascinated, rather to grow disgust on her. They eventually tied up their relationship by marriage. However by the end of their first year of marriage Moushumi became unfaithful and claimed that to marry with Gogol was her mistake and showed her regrets on this issue. Their marriage has been broken after Gogol has caught up that Moushumi has an sexual affair with her past old love. In Gogol's life he has seen many ups and downs regarding different issues but his own identity crisis was the big issue in his life. But at the end he was failed to resist his parents culture and traditions. Inside of his mind he always wanted to live in a peaceful place where his existence will be truly recognizable. Then again pondered over his identity, as he was born in America then he could never be an true Indian. And at the same time he could never be an true native Americans though he was by born an American citizen. His parent's culture and family values will resist him to call him an American. For this reason his relationships with American girls were never successful, and his marriage with an Indian girl was also not successful. In this way he always remained in a perpetual dilemma 


\section{GOGOL'S ENDEAVOUR TO ADJUST WITH BOTH THE INDIAN AND AMERICAN CULTURES}

From when Gogol has learnt about his nebulous name, he tried to make the amalgamation between the two countries cultures. In one part of his life, he was busy to satisfy his parents with Indian cultural norms and regulations. While on the other part of his life, Gogol tried to adjust himself with the American society. He was not taken as an American citizen by the American society though he was born in America. To make this complex situation become easy, Gogol did get the idea of changing his name to Nikhil from Gogol in order to live in the present. But unconsciously he did sign his old name, also when anyone called him Nikhil he didn't respond to that person immediately. He was somehow feeling blackout in his activities, he was shattered from his inner soul and thought to make him as a different person. Whenever the name Nikhil has come as an American names, soon after that his past name Gogol became attached with him everywhere. He was feeling like he belongs to nowhere and considered an ABCD (American Born Confused Desi) this was the most complex feelings of Gogol where he tried to consider himself as an American, but the American society made him feeling something different.

"But you're Indian" (Lahiri, 157)

The Americans didn't welcome him as a man of their clan, and at the same time Gogol had also no intense and lovable feelings about India and their cultures. What he did show the love for India was only to satisfy his parents. So in his mind some questions has been emerged about who is he? What should be his true identity? From where does he belongs? To where his life might go? Is there no way to come out from this identity loss? Is it the name which is the centre of all problems? All these questions were unanswered in his every steps of life, he was somewhat distorted which we can notice in all his love affairs with different woman. Gogol didn't want to introduce her girl friends Ruth or Maxine with his parents because he knew that his parents won't like that. As they were so Indians from heart and soul. On the other hands, in the case of Moushumi, Gogol's mother was in love with her but Gogol didn't want to marry an Indian girl. Here again came the questions of home country and host country's cultural diversity and conflicts. At the end of this novel, Gogol was able to negotiate his life with his past and present when he has lost his father. He has learnt to weave the Indian and American cultures together and also understood that his identity will sustain by both the cultures and heritage. To support this thoughts of Gogol here i would like to impose one idea of Stuart Hall. He remarked,

"Identity as a production, which is never complete, always in process, and always constituted, not outside representation" ( Hall, 10).

Instead of feeling ashamed Gogol thought he should blend his two countries identity and represents that as his pride. He has decided to uphold his parents culture and values while on the other sides, he tried to accumulate and adjust himself with American cultures and their people. Gogol has accepted his name as Nikhil Gogol Ganguli with a rearranged identity where he didn't feel any importance or need to grab any particular culture but the amalgamation of both the cultures.

\section{CONCLUSION}

Diaspora or hybrid Identity means the complexities regarding the immigrants identity. Here in The Namesake Jhumpa Lahiri tried to present the immigrants ambiguous life through the character Gogol. Gogol was neither be placed in his parent's homeland where he was bound to return, nor to that country where he has settled down in. As a result he has faced the crisis of hybrid identity. This hybrid or dual identity made Gogol's life difficult and miserable. This was not only Gogol's complex situation of life but also to all Indian diaspora, regardless of their caste, creed, religion, and different culture and heritage. For the second generation people this diasporic issue is slightly different and complicated than the first generation diaspora community. Gogol faced this complexities as he had to follow his parents culture and values and forced to adhere them, while among his 
American peers he had to follow their rules and regulations. This was the two folds problematic situation for Gogol. When Gogol was in a panel discussion about Indian novels written in English, the discussion was gone towards the immigrants identity problems which was called ABCD ( American Born Confused Desi). Gogol has realized that his identity was embellished by two cultures. At the end of this novel Gogol has found solace as he did united with his name and his parents culture and heritage. At the last hour of the novel, Gogol entered into his room like strolled and took the book he had forsaken once. Gogol got the feelings as a rescued person from an abandoned life. The crisis of dual identity was terribly faced by Gogol throughout this novel named The Namesake. At last he has made up his mind to negotiate with the two different cultures and had a solemn pledge to synthesize the both cultural values and rules.

\section{REFERENCES}

Batra, Jagdish. Jhumpa Lahiri's The Namesake, A Critical Study. New Delhi: Prestige Books, 2010

Hall, Stuart. "Cultural Identity and Diaspora" Contemporary Post Colonial Theory: A Reader, ed. Padmini Mongia. New Delhi: Oxford University Press, 1997, Seventh Impression. 2010. Print.

Lahiri, Jhumpa. The Namesake, New Delhi: Harper Collins, (2004).

Citation: Farhana Haque, M.A, Department of English and Humanities, Brac University, Mohakhali, Dhaka, Bangladesh Contestation and Negotiation of Gogol's Life Regarding His Hybrid Identity in Jhumpa Lahiri's The Namesake ARJEL Volume 2016; pp:1-7

Copyright (C) 2016 Farhana Haque, M.A This is an open access article distributed under the Creative Commons Attribution License, which permits unrestricted use, distribution, and reproduction in any medium, provided the original work is properly cited. 